\title{
PENGEMBANGAN PERANGKAT PEMBELAJARAN FISIKA BERBASIS INKURI TERBIMBING UNTUK MELATIHKAN KETERAMPILAN PROSES SAINS DAN MENINGKATKAN HASIL BELAJAR PADA TOPIK SUHU DAN PERUBAHANNYA
}

\author{
Sudiarman $^{1)}$, Soegimin, W.W ${ }^{2)}$ Endang Susantini ${ }^{3)}$ \\ ${ }^{1)}$ Mahasiswa Program Studi Pendidikan Sains, Program Pascasarjana Universitas Negeri Surabaya \\ ${ }^{2), 3)}$ Dosen Pascasarjana Prodi Pendidikan Sains Univesrtitas Negeri Surabaya \\ E-mail: sudiarman.arman@gmail.com
}

\begin{abstract}
This reseach aims to develop a physics learning material based on guided inquiry to facilate the students' science process skills are valid, practical and effective. Learning material was developed using 3-D models (define, design, develop) were tested using a one group pretest-posttest design. Learning material was tryouted class VII SMPN 1 Muara Jawa in academic year 2014/2015. The data collection through observation, tests and questionnaires. The data analysis techniques use qualitative analysis and descriptive analysis of quantitative. The results obtained demonstrate the validity of the learning material that includes lesson plans, worksheets, textbooks and students the knowledge and skills assessment sheet of a valid category. Practicality implementation of learning material that includes lesson plans and students' activities of a good category. The learning material developed is effective in terms of achievement learning indicators and learning outcomes of individual completeness increases, the positive students' response to learning. Based on these results, it can be conclude that the physics learning material based on guided inquiry are valid, practical and effective for use in teaching and learning and can to facilate the science process skills in junior high school students'.
\end{abstract}

Key words: Learning material, Guided inquiry, Science process skills.

\begin{abstract}
Abstrak: Penelitian ini bertujuan untuk mengembangkan perangkat pembelajaran fisika SMP berbasis inkuiri terbimbing untuk melatihkan keterampilan proses sains yang valid, praktis dan efektif. Perangkat pembelajaran dikembangkan menggunakan model 3-D (define, design, develop) yang diujicobakan menggunakan One Group Pretest-Posttest Design. Uji coba perangkat pembelajaran dilaksanakan pada siswa kelas VII SMPN 1 Muara Jawa tahun pelajaran 2014/2015. Pengumpulan data dilakukan melalui observasi, tes dan angket. Analisis data dilakukan dengan cara analisis kualitatif dan deskriptif kuantitatif. Hasil yang diperoleh menunjukkan validitas perangkat yang meliputi RPP, LKS, Buku ajar siswa dan Lembar Penilaian pengetahuan serta keterampilan berkategori valid. Kepraktisan perangkat pembelajaran yang meliputi keterlaksanaan RPP dan aktivitas siswa berkategori baik. Perangkat pembelajaran yang dikembangkan adalah efektif ditinjau dari ketercapaian indikator pembelajaran serta ketuntasan hasil belajar individual yang meningkat, respon siswa positif terhadap pembelajaran. Berdasarkan hasil tersebut, dapat disimpulkan bahwa perangkat pembelajaran fisika berbasis inkuiri terbimbing yang dikembangkan berkategori valid, praktis dan efektif untuk digunakan dalam proses belajar mengajar serta dapat melatihkan keterampilan proses sains kepada siswa SMP.
\end{abstract}

Kata-kata kunci: Perangkat pembelajaran, Inkuiri terbimbing, Keterampilan proses sains.

\section{PENDAhuluan}

Pendidikan sebagai salah satu alat mencerdaskan bangsa dan upaya meningkatkan status sosial masyarakat Indonesia bukanlah sesuatu yang statis melainkan sesuatu yang dinamis sehingga perlu disusun, didesain dan dievaluasi serta dikembangkan sedemikian rupa agar pendidikan dimasa mendatang menjadi lebih baik lagi. Pendidikan tidak hanya ditekankan pada penguasaan materi, tetapi juga ditekankan pada penguasaan keterampilan. Peserta didik juga harus memiliki kemampuan untuk berbuat sesuatu dengan menggunakan proses dan prinsip keilmuan yang telah dikuasai, dengan kata lain learning to know (pembelajaran untuk tahu) dan learning to do (pembelajaran untuk berbuat) harus dicapai dalam kegiatan belajar mengajar (Dewi, dkk., 2013; Ambarsari, 2013).

Konsep pembelajaran IPA yang dijelaskan sejak KTSP sampai kurikulum 2013 meliputi empat unsur utama yaitu: (1) produk, (2) proses, (3) aplikasi dan (4) sikap. IPA bersifat open ended karena selalu berkembang mengikuti pola perubahan dinamika dalam masyarakat. Salah satu dari empat unsur utama pada konsep pembelajaran IPA yang dijelaskan dalam 
kurikulum 2013 adalah proses, yaitu prosedur pemecahan masalah melalui metode ilmiah; metode ilmiah meliputi pengamatan, penyusunan hipotesis, perancangan eksperimen, percobaan atau penyelidikan, pengujian hipotesis melalui eksperimentasi; evaluasi, pengukuran, dan penarikan kesimpulan. Keterampilanketerampilan tersebut juga merupakan keterampilan proses sains (Kemendikbud, 2013).

Pinto dan Boudamoussi (2009) mengungkapkan bahwa keterampilan proses ini juga dijadikan sebagai salah satu dimensi penting yang diukur dalam literasi sains oleh Programme for International Student Assessmaent (PISA). Dari hasil tes PISA 2009 yang dilakukan oleh PISA, Indonesia masih berada di bawah rata-rata Internasional dengan skor 383 dari skor internasional 500 dengan peringkat 60 dari 65 anggota Negara peserta untuk bidang studi sains (Balitbang, Kemendikbud, 2013).

Hasil wawancara dan observasi di SMP Negeri 1 Muara Jawa, ditemukan beberapa penyebab belum maksimalnya upaya untuk melatihkan keterampilan proses sains dalam pembelajaran fisika, yaitu: 1) Guru tidak memiliki banyak waktu untuk mengembangkan perangkat pembelajaran IPA yang secara khusus untuk melatihkan keterampilan proses sains; 2) Belum tersedianya perangkat pembelajaran fisika yang berbasis inkuiri terbimbing untuk melatihkan keterampilan proses sains, khususnya pada topik suhu dan perubahannya; dan 3) Pembelajaran yang berpusat pada guru menyebabkan siswa kurang termotivasi dalam belajar fisika yang berdampak pada rendahnya hasil belajar fisika. Berdasarkan permasalahan di atas maka diperlukan sebuah perangkat pembelajaran yang secara khusus dapat melatihkan keterampilan proses sains pada materi suhu dan perubahannya di SMP.

Keterampilan proses sains dibedakan menjadi 2 kelompok yaitu keterampilan dasar proses sains dan keterampilan proses terintegrasi (Dimyati dan Mudjiono, 2009). Keterampilan proses dasar sains terdiri atas mengamati, mengklasifikasi, mengukur, mengkomunikasikan, memprediksi, dan menyimpulkan. Keterampilan proses sains terintegrasi meliputi merumuskan masalah, merumuskan hipotesis, mengidentifikasi dan mendefinisikan variabel, merancanakan dan melakukan penyelidikan, memperoleh dan menyajikan data, menganalisis data, dan merumuskan kesimpulan.

Keterampilan proses sains pada pembelajaran fisika dapat dilatihkan dengan memilih metode pembelajaran yang tepat. Metode pembelajaran yang diharapkan dapat melatih peserta didik dalam keterampilan proses sains adalah metode pembelajaran inkuiri (Subagyo, dkk., 2009). Metode pembelajaran inkuiri adalah metode yang memberikan penekanan pada keterlibatan siswa dalam proses belajar baik secara mental maupun fisik yang dapat diterapkan pada jenjang SMP sebagai sarana untuk mengembangkan kemampuan siswa dalam pemecahan masalah mulai dari yang sangat sederhana sampai pada yang lebih kompleks.

Tingkatan inkuiri dapat disesuaikan dengan tingkat perkembangan mental dan intelektual peserta didik (Kim dan Kellough, 1995). Hal ini dimaksudkan bahwa intensitas bimbingan dari guru dapat semakin dikurangi seiring dengan semakin dewasanya anak. Orlich, et al. (1998) mengemukakan metode pembelajaran inkuiri dapat dibedakan menjadi inkuiri terbimbing dan inkuiri tak terbimbing.

Peserta didik perlu didorong untuk mengonstruksi pengetahuan di dalam pikirannya (Schwarz dan Gwekwerere, 2007). Peserta didik juga perlu didorong untuk bekerja memecahkan masalah serta menemukan segala sesuatu untuk dirinya, agar dapat memahami dan menerapkan pengetahuan. Intinya pembelajaran harus bergeser dari "diberi tahu" menuju "aktif mencari tahu”.

Metode pembelajaran inkuri terbimbing memberikan kesempatan bagi peserta didik untuk berdiskusi dan bekerja sama dalam berbagai bentuk untuk menyelesaikan tugas peserta didik (Maloney \& Simon, 2007). Guru memberikan sejumlah besar bantuan kepada peserta didik selama tahap-tahap awal pembelajaran, selanjutnya peserta didik mengambil alih tanggung-jawab yang semakin besar segera setelah ia dapat melakukannya (Slavin, 2008).

Model inkuiri terbimbing terdiri dari enam fase, yaitu: 1) Menyajikan pertanyaan atau masalah; 2) Membuat hipotesis; 3) Merancang percobaan; 4) Melakukan percobaan untuk memperoleh informasi; 5) Mengumpulkan data; 6) Membuat kesimpulan (Eggen dan Kauchak, 1996). Pada pembelajaran inkuiri terbimbing guru memfasilitasi peserta didik untuk berkolaborasi sehingga peserta didik dapat bekerja sama untuk menyelesaikan masalah dengan menggunakan keterampilan proses sains (Ambarsari, 2013; Ibrahim, 2012; Maloney \& Simon, 2007).

Suhu adalah besaran yang menyatakan derajat panas dingin suatu benda dan alat yang digunakan untuk mengukur suhu adalah termometer. Materi suhu dan perubahannya akan sangat menarik dan bermakna apabila disajikan dengan menggunakan metode ilmiah yang dapat dilatihkan melalui keterampilan proses sains menggunakan metode pembelajaran berbasis inkuri terbimbing. Hal tersebut didasarkan pada kompetensi inti keterampilan yang mewajibkan siswa harus mencoba, mengolah, dan menyaji dalam ranah konkret dan abstrak, serta kompetensi dasar keterampilan yang mewajibkan siswa harus dapat melakukan percobaan untuk menyelidiki suhu dan perubahannya (Kemendikbud, 2013). 
Pembelajaran inkuri terbimbing mendorong peserta didik untuk belajar melalui keterlibatan aktif dengan keterampilan-keterampilan, konsep-konsep, dan prinsip-prinsip. Pada pembelajaran inkuri terbimbing guru mendorong peserta didik untuk mendapatkan pengalaman dan pembelajaran terjadi apabila peserta didik terlihat secara aktif dalam menggunakan keterampilan proses sains siswa yang sangat relevan dengan fase model inkuiri terbimbing misalnya mengamati, menanya dan merumuskan masalah, merumuskan hipotesis, mengidentifikasi dan mendefinisikan variabel percobaan, merancang dan melaksanakan eksperimen, mengumpulkan dan menganalisis data, menarik kesimpulan, serta menyajikan hasil kerjanya.

\section{METODE PENELITIAN}

Jenis penelitian ini adalah penelitian pengembangan yaitu mengembangkan perangkat pembelajaran fisika SMP dengan model inkuiri terbimbing pada topik suhu dan perubahannya untuk melatihkan keterampilan proses sains dan meningkatkan hasil belajar siswa pada siswa SMPN 1 Muara Jawa. Perangkat pembelajaran yang dikembangkan meliputi rencana pelaksanaan pembelajaran (RPP), lembar kegiatan siswa (LKS), buku ajar topik suhu dan perubahannya, dan penilaian hasil belajar siswa.

Penelitian ini dilengkapi dengan instrumen yang diperlukan dalam proses pengambilan data yaitu, lembar validasi perangkat pembelajaran, lembar pengamatan keterlaksanaan rencana pelaksanaan pembelajaran (RPP), lembar pengamatan aktivitas siswa, angket respon siswa, lembar penilaian kompetensi pengetahuan, lembar penilaian kompetensi keterampilan, lembar penilaian kompetensi sikap siswa.

Perangkat pembelajaran dikembangkan menggunakan rancangan four-D model yang dikembangkan oleh Thiagarajan, Semmel, dan Semmel (1974). Model four-D dipilih karena sistematis dan cocok untuk mengembangkan perangkat pembelajaran, seperti yang terlihat pada Gambar 1 di bawah ini.

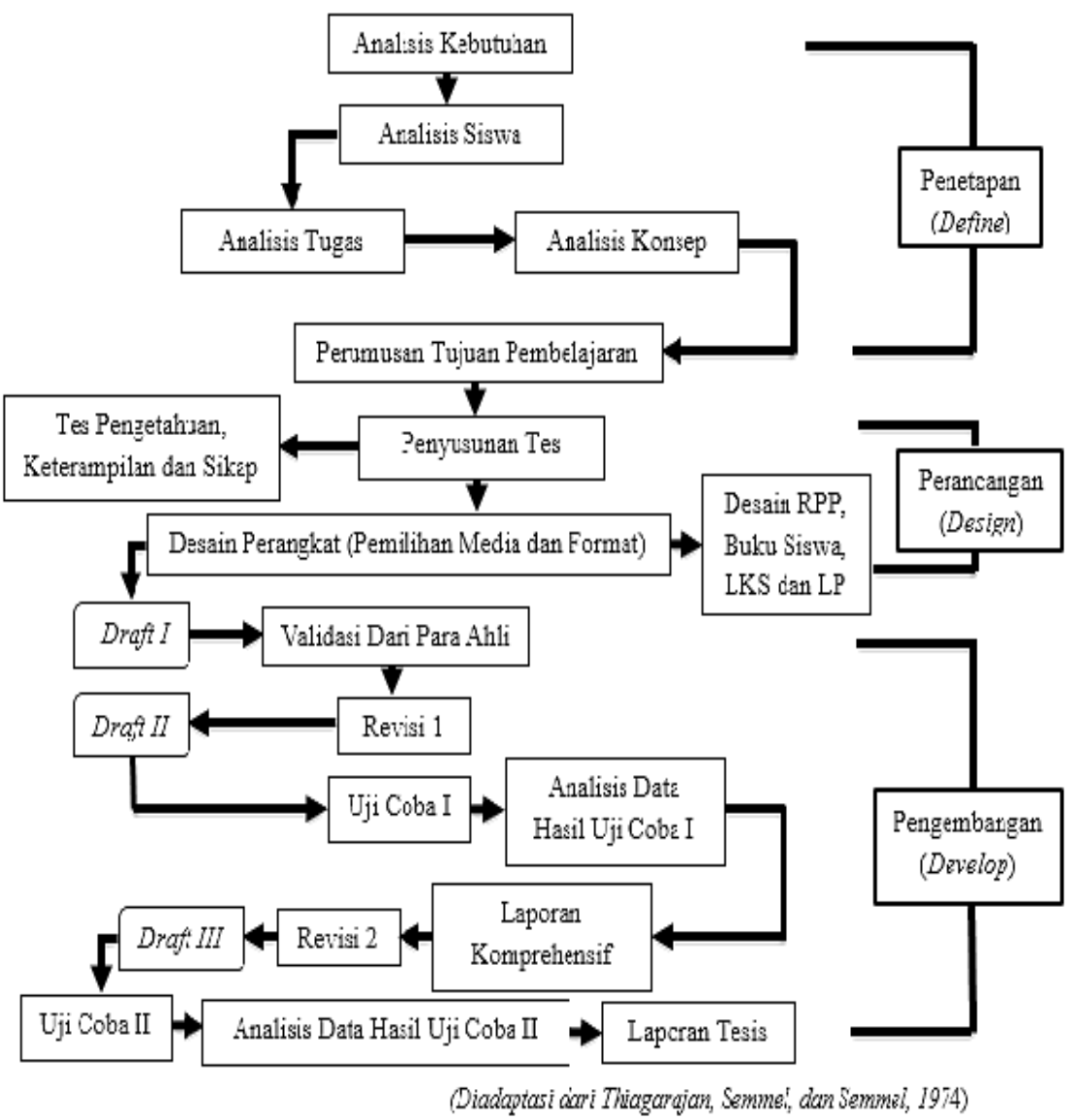

Gambar 1. Tahap-tahap pelaksanaan penelitian pengembangan perangkat

Rancangan four-D terdiri atas empat tahap, yaitu tahap penetapan (define), tahap merancang (design), tahap pengembangan (develop) dan tahap menyebarluaskan (disseminate) (Thiagarajan, Semmel, dan Semmel, 1974). Pada penelitian ini, tidak sepenuhnya melakukan semua tahap yang ada pada model four- $D$, penelitian ini hanya menggunakan tiga tahap saja sampai pada tahap pengembangan (develop) karena keterbatasan tenaga, waktu dan biaya penelitian sehingga model pengembangan $4 D$ dipersempit menjadi model $3 D$. 
Implementasi perangkat pembelajaran pada penelitian ini menggunakan Pre-test and Post-test Group Design pada satu kelompok subyek (Tuckman, 1999). Pada langkah pertama dilakukan pengukuran sebagai uji awal, selanjutnya diberi perlakuan dalam jangka waktu tertentu (tiga kali pertemuan), kemudian dilakukan uji akhir. Gambaran implementasi perangkat pembelajaran pada penelitian ini adalah sebagai berikut:

$$
\begin{array}{lll}
O_{1} & X & O_{2}
\end{array}
$$

\section{Keterangan:}

$O_{1}=\mathrm{Uji}$ awal (pre test) untuk mengetahui penguasaan siswa terhadap materi pelajaran sebelum pembelajaran.

$X=$ Perlakuan dengan menerapkan perangkat pembelajaran berbasis inkuiri terbimbing untuk melatihkan keterampilan proses sains.

$\mathrm{O}_{2}=\mathrm{Uji}$ akhir (post test) untuk mengetahui penguasaan siswa terhadap materi pelajaran sesudah pembelajaran.

\section{A. Tehnik Pengumpulan Data}

Pengumpulan data dalam penelitian ini menggunakan metode dan teknik sebagai berikut:

1. Validasi

Validasi perangkat dilakukan sebelum perangkat diterapkan di sekolah, validasi dilakukan untuk mengetahui validitas perangkat pembelajaran yang dikembangkan. Validasi dilakukan oleh pakar (validator) dengan menggunakan lembar validasi selama kurang lebih satu minggu.

\section{Observasi}

Observasi dilakukan untuk mengumpulkan data penelitian berupa penilaian terhadap keterlaksanaan rencana pelaksanaan pembelajaran, aktivitas siswa, dan sikap selama proses kegiatan belajar mengajar, yang dilakukan oleh dua orang pengamat, dalam melakukan pengamatan, pengamat duduk di tempat yang tidak menggangu proses pembelajaran dan memungkinkan untuk dapat melihat seluruh aktivitas di dalam kelas selama proses belajar mengajar berlangsung. Observasi juga dilakukan untuk mengamati kendala-kendala yang terjadi selama proses kegiatan belajar mengajar.

\section{Angket}

Angket digunakan untuk mendapatkan informasi tentang respon siswa terhadap kegiatan pembelajaran dan perangkat yang digunakan dalam proses belajar mengajar. Pengisian angket dilakukan setelah proses kegiatan belajar mengajar selesai dilaksanakan.

4. Tes

Tes hasil belajar kompetensi pengetahuan, kompetensi keterampilan dan kompetensi sikap yang digunakan meliputi tes awal yang dilakukan di awal proses belajar mengajar, digunakan untuk mengukur persiapan siswa untuk menerima konsep yang diajarkan. Tes hasil belajar yang dilakukan pada akhir proses belajar mengajar bertujuan untuk mengetahui ketuntasan indikator, ketuntasan individual, dan sensitivitas butir soal.

Instrumen penelitian adalah alat untuk mengumpulkan data. Instrumen yang digunakan dalam penelitian ini adalah:

1. Instrumen Validasi Perangkat Pembelajaran

Instrumen validasi perangkat, meliputi: rencana pelaksanaan pembelajaran, buku siswa, LKS dan LP. Perhitungan reliabilitas instrumen penilaian perangkat pembelajaran digunakan rumus sebagai berikut:

$$
\text { Percentace agreement }=100\left(1-\frac{A-B}{A+B}\right)
$$

Keterangan:

$$
\begin{aligned}
& \mathrm{R}=\text { Reliabilitas instrumen (Percentage of } \\
& \text { agreement) } \\
& \mathrm{A}=\text { Frekuensi penilaian oleh validator yang } \\
& \text { memberikan nilai tinggi } \\
& \mathrm{B}=\text { Frekuensi penilaian oleh validator yang } \\
& \text { memberikan nilai rendah. }
\end{aligned}
$$

Instrumen penilaian perangkat dikatakan reliabel, apabila reliabilitasnya $\geq 75 \%$ (Borich, 1994).

2. Instrumen Kepraktisan Perangkat Pembelajaran.

a. Lembar keterlaksanaan RPP, Lembar keterlaksanaan diisi oleh pengamat.

b. Lembar aktivitas siswa saat proses belajar mengajar. Lembar pengamatan aktivitas siswa diisi oleh orang dua pengamat.

Koefesien reliabilitas instrument pengamatan diperoleh dengan menggunakan teknik Inter observer agreement, yaitu menghitung persentase kesesuaian antara kedua hasil pengamatan dari para pengamat. Rumus yang dianjurkan oleh Emmer dan Millet (dalam Borich, 1994), yaitu:

$$
\text { Percentace agreement }=100\left(1-\frac{A-B}{A+B}\right)
$$

Keterangan:

$$
\begin{aligned}
& \text { A = Frekuensi aktivitas siswa yang teramati oleh } \\
& \text { pengamat dengan memberikan frekuensi } \\
& \text { tinggi } \\
& \text { B = Frekuensi aktivitas siswa yang teramati oleh } \\
& \text { pengamat dengan memberikan frekuensi } \\
& \text { rendah }
\end{aligned}
$$

Kreteria penilaian instrumen dikatakan memiliki tingkat reliabilitas yang baik jika diperoleh koefesien reliabilitas $\geq 75 \%$ (Borich, 1994). 
3. Instrumen Kefektifan Perangkat Pembelajaran.

a. Lembar Penilaian (LP) meliputi, LP pengetahuan, LP keterampilan proses sains, LP sikap yang dikembangkan berdasarkan kurikulum 2013. LP digunakan untuk mengetahui ketuntasan indikator pembelajaran, individual.

b. Angket respon siswa. Angket respon siswa digunakan untuk memperoleh respon siswa terhadap proses belajar mengajar dengan inkuiri terbimbing untuk melatihkan keterampilan proses sains.

Perangkat meliputi, RPP, buku siswa, LKS dan LP yang dikembangkan selanjutnya dilakukan validasi oleh pakar dalam bidang pendidikan. Data hasil penelitian dianalisis secara deskriptif. Passing grade atau skor rerata $(\mathrm{P})$ dari hasil penilaian para pakar disesuaikan dengan kriteria penilaian perangkat pembelajaran sebagai berikut:

Tabel 1. Kriteria pengkategorian penilaian validasi RPP, buku siswa, dan LKS

\begin{tabular}{|c|c|l|}
\hline $\begin{array}{c}\text { Interval } \\
\text { Skor }\end{array}$ & $\begin{array}{c}\text { Kategori } \\
\text { Penilaian }\end{array}$ & \multicolumn{1}{|c|}{ Keterangan } \\
\hline $3,6 \leq \mathrm{P} \leq 4$ & Sangat valid & $\begin{array}{l}\text { Dapat digunakan tanpa } \\
\text { revisi }\end{array}$ \\
\hline $2,6 \leq \mathrm{P} \leq 3,5$ & Valid & $\begin{array}{l}\text { Dapat digunakan } \\
\text { dengan sedikit revisi }\end{array}$ \\
\hline $1,6 \leq \mathrm{P} \leq 2,5$ & Kurang valid & $\begin{array}{l}\text { Dapat digunakan } \\
\text { dengan banyak revisi }\end{array}$ \\
\hline $1 \leq \mathrm{P} \leq 1,5$ & Tidak Valid & $\begin{array}{l}\text { Belum dapat } \\
\text { digunakan dan masih } \\
\text { memerlukan } \\
\text { konsultasi }\end{array}$ \\
\hline
\end{tabular}

diadaptasi dari (Ratumanan dan Laurens, 2006)

Tabel 2. Kriteria pengkategorian penilaian LP

\begin{tabular}{|c|c|}
\hline Interval Skor & Kategori Penilaian \\
\hline $\mathrm{X}>4,65$ & Sangat baik \\
\hline $3,45<\mathrm{X} \leq 4,64$ & Baik \\
\hline $1,15<\mathrm{X} \leq 3,45$ & Cukup \\
\hline $0,35<\mathrm{X} \leq 1,15$ & Jelek \\
\hline $\mathrm{X} \leq 0,35$ & Sangat jelek \\
\hline
\end{tabular}

(Arikunto, 2006)

\section{B. Analisis Keterlaksanaan RPP}

Pengamatan keterlaksanaan RPP dilakukan oleh pengamat yang telah dilatih memberikan penilaian yang tepat pada instrumen yang disediakan. Kriteria setiap fase pembelajaran dinilai dengan memberikan tanda $(\sqrt{ })$ pada kolom penilaian (4: sangat baik, 3: baik, 2: cukup baik, 2: kurang baik). Data dianalisis secara deskriptif kualitatif dengan teknik persentase sebagai berikut:

$$
P=\frac{\sum K}{\sum N} \times 100 \%
$$

Keterangan:

$\mathrm{P}=$ Persentase keterlaksanaan RPP

$\sum \mathrm{K}=$ Jumlah skor rata-rata seluruh aspek yang terlaksana

$\sum \mathrm{N}=$ Jumlah skor maksimum seluruh aspek yang diamati

Persentase keterlaksanaan RPP menggunakan kriteria sebagai berikut:

Tabel 3. Kriteria pengkategorian keterlaksanaan RPP

\begin{tabular}{|c|c|}
\hline Interval persentase & Kategori keterlaksanaan \\
\hline $75 \%-100 \%$ & Terlaksana sangat baik \\
\hline $50 \%-74 \%$ & Terlaksana dengan baik \\
\hline $25 \%-49 \%$ & Kurang terlaksana \\
\hline $0 \%-24 \%$ & Tidak terlaksana \\
\hline
\end{tabular}

Sedangkan untuk penilaian keterlaksanaan RPP pada setiap fase, ditentukan dengan membandingkan rata-rata skala penilaian yang diberikan dua pengamat dengan kriteria penilaian sebagai berikut:

Tabel 4. Kriteria penilaian keterlaksanaan RPP

\begin{tabular}{|c|c|}
\hline Interval & Penilaian Keterlaksanaan \\
\hline $3,50-4,00$ & Sangat baik \\
\hline $2,50-3,49$ & Baik \\
\hline $1,50-2,49$ & Cukup baik \\
\hline $1,00-1,49$ & Tidak baik \\
\hline
\end{tabular}

Diadaptasi dari (Ratumanan dan Laurens, 2011)

\section{Analisis Aktivitas Siswa}

Analisis aktivitas siswa adalah segala kegiatan yang dilakukan siswa selama proses belajar mengajar berlangsung dan diamati oleh dua orang pengamat dengan menggunakan instrumen pengamatan aktivitas siswa. Data yang diperoleh kemudian dianalisis secara deskrptif dengan menggunakan rumus sebagai berikut:

$$
P=\frac{\sum A}{\sum N} \times 100 \% \quad \text { (Arifin, 2010) }
$$

Keterangan:

$\mathrm{P}=$ Persentase

$\sum \mathrm{A}=$ Jumlah frekuensi tiap aktivitas yang muncul

$\sum \mathrm{N}=$ Jumlah total frekuensi aktivitas.

\section{Analisis Hasil Belajar}

Analisis hasil belajar dilakukan berdasarkan data hasil belajar pretest dan posttest tes kognitif (pengetahuan dan keterampilan proses sains) dan sikap yang dianalisis secara deskriptif kuantitatif yang terdiri dari: 
1. Hasil belajar kognitif (pengetahuan dan keterampilan proses sains).

a. Ketercapaian Indikator Pembelajaran

Ketercapaian Indikator pembelajaran dihitung dengan menggunakan rumus:

Ketercapaian indikator

$$
=\frac{\sum \text { Siswa yang mencapai indikator }}{\sum \text { Siswa }} \times 100 \%
$$

Indikator pembelajaran dikatakan tercapai apabila persentase ketercapaian indikator pembelajaran $\geq 75 \%$.

b. Ketuntasan Individual

Siswa telah tuntas secara individual, apabila rata-rata ketercapaian indikator memenuhi ketuntasan minimal untuk seluruh kompetensi dasar pada kompetensi pengetahuan dan kompetensi keterampilan yaitu 3,01 dengan predikat $\mathrm{B}+$. Data hasil pretest dan posttest kompetensi pengetahuan siswa dilakukan analisis $N$-Gain. Gain menunjukkan perbedaan kompetensi pengetahuan siswa sebelum dan setelah diberi perlakuan.

$$
\langle g\rangle=\frac{\text { Spost }- \text { Spre }}{S \max -\text { Spre }}
$$

Dengan :

$$
\begin{array}{ll}
\langle g\rangle & =\text { Nilai gain } \\
\text { Spost } & =\text { Nilai post-test } \\
\text { Spre } & =\text { Nilai pre-test } \\
\text { Smax } & =\text { Nilai maksimal }
\end{array}
$$

Selanjutnya dari hasil perhitungan $N$-gain tersebut kemudian dikonversi dengan kriteria sebagai berikut:

Tabel 5 Kriteria normalized gain

\begin{tabular}{|l|l|}
\hline \multicolumn{1}{|c|}{ Skor $\mathbf{N - G a i n}$} & \multicolumn{1}{|c|}{$\begin{array}{c}\text { Kriteria Normalized } \\
\text { Gain }\end{array}$} \\
\hline $0.70<N$-Gain & Tinggi \\
\hline $0.30 \leq N$-Gain $\leq 0.70$ & Sedang \\
\hline$N$-Gain $<0.30$ & Rendah \\
\hline
\end{tabular}

(Hake, 1999)

c. Sensitivitas

Indeks sensitivitas dari suatu butir soal merupakan ukuran seberapa baik butir soal membedakan antara siswa yang telah menerima pembelajaran dengan siswa yang belum menerima pembelajaran. Indeks sensitifitas yang efektif berada antara $0,00-1,00 \quad(0,00<\mathrm{S}<1,00)$ semakin mendekati angka 1,00 menunjukkan kepekaan butir soal dengan efek pembelajaran semakin besar (Gronlund, 1982). Butir soal dikatakan peka apabila sensitifitas setiap butir soal $\geq 0,30$ (Aiken, 1997).
Rumus yang digunakan yaitu:

$$
S=\frac{R_{A}-R_{B}}{T}
$$

(Gronlund, 1982)

Keterangan:

$\mathrm{S}=$ Indeks sensitivitas butir soal

$\mathrm{T}=$ Jumlah siswa yang mengikuti tes

$\mathrm{R}_{\mathrm{A}}=$ Jumlah siswa yang menjawab benar pada tes akhir (posttest)

$\mathrm{R}_{\mathrm{B}}=$ Jumlah siswa yang menjawab benar pada tes awal (pretest).

1) Hasil belajar sikap (sikap ilmiah)

Untuk menganalisis hasil belajar sikap siswa dilakukan dengan menggunakan rumus:

$$
P=\frac{\text { Jumlah skor rata }- \text { rata penilaian per aspek }}{\text { Jumlah skor maksimum penilaian per aspek }} \times 100 \%
$$

Tabel 6 Kriteria penilaian sikap siswa

\begin{tabular}{|c|c|c|}
\hline No & Persentase (\%) & Kategori \\
\hline 1 & $\geq 89$ & Sangat Baik \\
\hline 2 & $67 \leq \mathrm{P}<89$ & Baik \\
\hline 3 & $34 \leq \mathrm{P}<67$ & Cukup \\
\hline 4 & $\mathrm{P}<34$ & Kurang \\
\hline
\end{tabular}

a. Analisis Respon Siswa

Angket respon siswa digunakan untuk mengetahui pendapat siswa terhadap penerapan perangkat pembelajaran yang dikembangkan. Respon siswa dianalisis secara deskriptif dengan persentase sebagai berikut:

$$
P=\frac{\sum R}{\sum N} \times 100 \%
$$

Keterangan:

$\mathrm{P}=$ Persentase

$\sum \mathrm{R}=$ Jumlah respon positif

$\sum \mathrm{N}=$ Jumlah keseluruhan respon.

Persentase respon siswa dikonversi dengan kriteria sebagai berikut:

Tabel 7. Kriteria respon siswa berdasarkan persentase respon siswa

\begin{tabular}{|c|c|}
\hline Angka Persentase & Kategori \\
\hline $81 \%-100 \%$ & Sangat kuat \\
\hline $61 \%-80 \%$ & Kuat \\
\hline $41 \%-60 \%$ & Cukup \\
\hline $21 \%-40 \%$ & Lemah \\
\hline $0 \%-20 \%$ & Sangat Lemah \\
\hline
\end{tabular}

(Ridwan, 2010) 


\section{HASIL PENELITIAN DAN DISKUSI}

Penelitian ini menghasilkan perangkat pembelajaran yang terdiri dari rencana pelaksanaan pembelajaran (RPP), buku siswa, lembar kegiatan siswa (LKS), dan lembar penilaian untuk aspek pengetahuan, keterampilan dan sikap yang telah divalidasi oleh tiga orang validator dan telah dilakukan penelitian di SMP Negeri 1 Muara Jawa Kabupaten Kutai Kartanegara Provinsi Kalimantan Timur pada siswa kelas VII. Deskripsi mengenai hasil pengembangan perangkat pembelajaran dan hasil implementasi perangkat pembelajaran akan diuraikan di bawah ini.

\section{A. Deskripsi Hasil Validasi Perangkat Pembelajaran}

Validasi perangkat pembelajaran dilakukan untuk mendeskripsikan validitas perangkat pembelajaran yang dibuat dalam sebuah penelitian. Deskripsi validasi perangkat pembelajaran diperoleh dengan mengacu pada penilaian dan saran dari pakar. Penilaian dan saran dari validator juga digunakan sebagai dasar untuk merevisi perangkat pembelajaran. Validasi perangkat pembelajaran dilakukan oleh pakar yang berkompeten dibidanganya. Perangkat pembelajaran yang divalidasi mencakup RPP, buku siswa, LKS dan lembar penilaian.

Hasil validasi yang dilakukan oleh beberapa pakar menunjukkan bahwa perangkat yang dikembangkan memiliki kriteria baik dan sangat baik, sehingga dapat dikategorikan valid untuk digunakan dalam penelitian. Hasil analisis secara umum dapat dilihat pada Tabel 8 di bawah ini.

Tabel 8. Hasil penilaian perangkat oleh validator

\begin{tabular}{|l|l|l|l|l|l|}
\hline \multirow{2}{*}{ N } & \multicolumn{2}{|c|}{ Validitas } & \multicolumn{2}{l|}{ Reliabilitas } \\
\cline { 3 - 6 } o & $\begin{array}{l}\text { Jenis } \\
\text { Perangkat }\end{array}$ & Nilai & $\begin{array}{l}\text { Perce } \\
\text { ntage } \\
\text { of } \\
\text { Kateg } \\
\text { ori } \\
1\end{array}$ & $\begin{array}{l}\text { Agree } \\
\text { ment } \\
(\%)\end{array}$ & $\begin{array}{l}\text { Katego } \\
\text { ri }\end{array}$ \\
\hline $\begin{array}{l}\text { Pelaksanaa } \\
\text { Pembelajar } \\
\text { an (RPP) }\end{array}$ & 3.71 & $\begin{array}{l}\text { Sangat } \\
\text { valid }\end{array}$ & 91,56 & Reliabel \\
\hline 2 & $\begin{array}{l}\text { Buku Ajar } \\
\text { Siswa } \\
\text { (MAS) }\end{array}$ & 3.76 & $\begin{array}{l}\text { Sangat } \\
\text { Valid }\end{array}$ & 91,69 & Reliabel \\
\hline 3 & $\begin{array}{l}\text { Lembar } \\
\text { Kerja } \\
\text { Siswa } \\
\text { (LKS) }\end{array}$ & 3.67 & $\begin{array}{l}\text { Sangat } \\
\text { Valid }\end{array}$ & 91,83 & Reliabel \\
\hline 4 & $\begin{array}{l}\text { Lembar } \\
\text { Penilaian } \\
\text { (LP) }\end{array}$ & 4,67 & $\begin{array}{l}\text { Sangat } \\
\text { baik }\end{array}$ & 91,47 & Reliabel \\
\hline
\end{tabular}

Tabel 8 di atas menunjukkan bahwa rata-rata nilai dari ketiga validator tiap komponen maupun seluruh komponen adalah 3,6 $\leq P \leq 4$ untuk RPP, buku siswa dan LKS, sehingga kategori tiap komponen memiliki klasifikasi sangat valid (Ratumanan dan Laurens, 2006). Hasil penilaian RPP meliputi aspek format, isi dan bahasa berkategori sangat valid dengan rata-rata 3,7 dan reliabilitas $91,56 \%$. Hasil penilaian buku siswa yang terdiri dari aspek kelayakan isi bahasa dan penyajian juga berkategori sangat valid dengan rata-rata 3,8 dan reliabilitas 91,69\%. Hasil penilaian untuk LKS juga memiliki kategori sangat baik yaitu dengan rata-rata 3,7 dan reliabilitas 91,83\%. Pada lembar penilaian untuk validitas isi soal berkategori baik, sebab berada pada rentang $3,45<\mathrm{X} \leq 4,64$, pada bahasa dan penulisan soal berkategori sangat baik, sebab berada pada rentang $X>4,65$ dengan rata-rata reliabilitas $91,47 \%$. Jadi seluruh perangkat yang pembelajaran yang dikembangkan secara keseluruhan termasuk dalam kategori reliabel sebab memiliki nilai reliabilitas $\geq 75$ (Borich, 1994).

\section{B. Deskripsi Hasil Analisis Kepraktisan Perangkat Pembelajaran}

Deskripsi hasil dan analisis data pengamatan pelaksanaan pembelajaran fisika berbasis inkuiri terbimbing untuk melatihkan keterampilan proses sains pada penelitian ini adalah sebagai berikut:

1. Keterlaksanaan Rencana Pelaksanaan Pembelajaran (RPP)

Rata-rata penilaian hasil pengamatan keterlaksanaan RPP disajikan pada Tabel 9.

Tabel 9. Hasil pengamatan keterlaksanaan RPP

\begin{tabular}{|l|l|c|l|}
\hline \multirow{2}{*}{$\begin{array}{l}\text { N } \\
\mathbf{0}\end{array}$} & $\begin{array}{l}\text { Aspek yang } \\
\text { dinilai }\end{array}$ & $\begin{array}{l}\text { Keterlaks } \\
\text { anaan } \\
\text { RPP }\end{array}$ & \multirow{2}{*}{ Kategori } \\
\cline { 2 - 3 } & Nilai & \\
\hline 1 & $\begin{array}{l}\text { Kegiatan } \\
\text { Pendahuluan }\end{array}$ & 3.76 & Sangat Baik \\
\hline 2 & Kegiatan Inti & 3.62 & Sangat Baik \\
\hline 3 & Kegiatan Penutup & 3.94 & Sangat Baik \\
\hline 4 & $\begin{array}{l}\text { Pengelolaan } \\
\text { waktu }\end{array}$ & 3.83 & Sangat Baik \\
\hline 5 & $\begin{array}{l}\text { Pengamatan } \\
\text { Suasana Kelas }\end{array}$ & 3.92 & Sangat Baik \\
\hline $\begin{array}{l}\text { Rata-rata nilai } \\
\text { keterlaksanaan RPP }\end{array}$ & 3.81 & Sangat Baik \\
\hline $\begin{array}{l}\text { Persentase } \\
\text { keterlaksanaan RPP }\end{array}$ & 93,29 & Sangat Baik \\
\hline
\end{tabular}

Tabel 9 menunjukkan bahwa pada penelitian ini, rata-rata persentase keterlaksanan RPP adalah 93,29\%, hal ini berarti RPP terlaksana dengan kriteria sangat baik dan dapat digunakan dalam kegiatan pengamatan keterlaksanaan pembelajaran.

Kegiatan pembelajaran dinyatakan juga dengan skor rata-rata tiap aspek. Tabel di atas menunjukkan bahwa guru dalam melaksanakan pembelajaran fisika berbasis inkuiri terbimbing untuk melatihkan keterampilan proses sains telah melaksanakan aspek 
pendahuluan, kegiatan inti, penutup, pengelolaan waktu dan pengelolaan suasana kelas memiliki rata-rata penilaian di atas 3,81 dengan ketegori sangat baik (Ratumanan dan Laurens, 2011), pada kegiatan inti terlihat guru dinilai masih kurang dalam meminta siswa mengumpulkan informasi yang berhubungan dengan permasalahan, membimbing dan meminta siswa tepat waktu (melatih disiplin) dalam melakukan percobaan dengan ketelitian dan kehati-hatian, serta memberikan penjelasan dalam merumuskan dan menyusun kesimpulan hasil percobaan dengan penuh jujur dan tanggung jawab, hal ini dikarenakan belum terbiasanya siswa dengan pembelajaran inkuiri terbimbing, sehingga hal ini juga berimbas pada kesulitan siswa dalam melakukan keterampilan proses sains.

Rekapitulasi hasil pengamatan keterlaksanaan rencana pelaksanaan pembelajaran berupa rata-rata skor pada aspek pendahuluan, kegiatan inti, penutup, pengelolaan waktu dan pengelolaan kelas ditunjukkan pada Gambar 2 berikut:

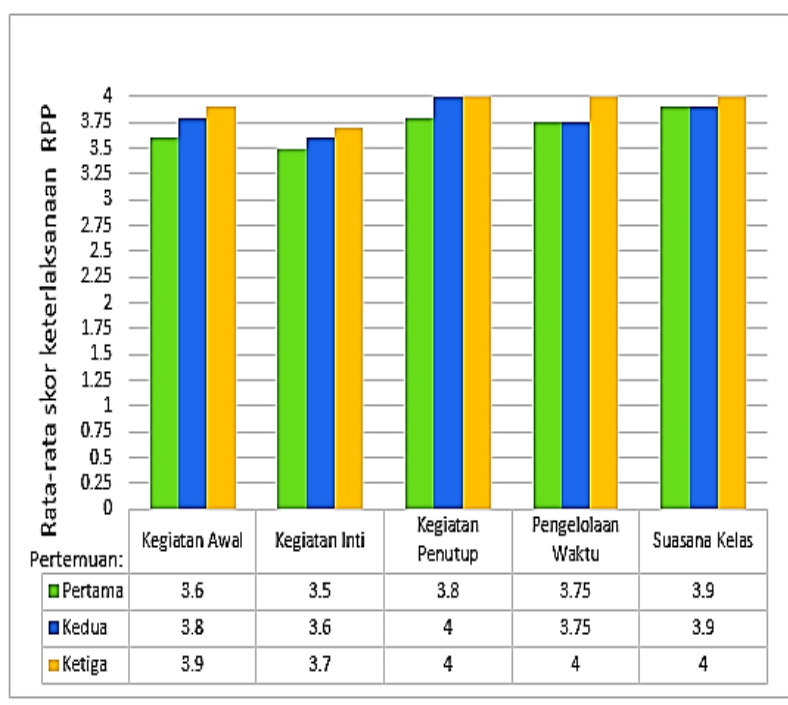

Gambar 2. Grafik rata-rata skor pengamatan keterlaksanaan RPP tiap aspek

\section{Aktivitas Siswa dalam Kegiatan Pembelajaran}

Pengamatan aktivitas siswa dalam kegiatan pembelajaran dilakukan oleh dua orang pengamat menggunakan lembar pengamatan aktivitas siswa. Ratarata hasil pengamatan aktivitas siswa pada penelitian ini disajikan pada Tabel 10 di bawah ini.

Tabel 10. Pengamatan aktivitas siswa

\begin{tabular}{|l|l|c|}
\hline No. & \multicolumn{1}{|c|}{ Aspek Yang Diamati } & $\begin{array}{c}\text { Rata-rata } \\
\text { aktivitas } \\
\text { siswa (\%) }\end{array}$ \\
\hline 1 & Merumuskan hipotesis & 5,3 \\
\hline 2 & $\begin{array}{l}\text { Mengidentifikasi variabel dan } \\
\text { merancang percobaan }\end{array}$ & 5,3 \\
\hline 3 & Melakukan percobaan & 30,5 \\
\hline 4 & $\begin{array}{l}\text { Menganalisis data hasil } \\
\text { percobaan dan menuliskan } \\
\text { kesimpulan }\end{array}$ & 15,0 \\
\hline
\end{tabular}

\begin{tabular}{|l|l|c|}
\hline No. & \multicolumn{1}{|c|}{ Aspek Yang Diamati } & $\begin{array}{c}\text { Rata-rata } \\
\text { aktivitas } \\
\text { siswa (\%) }\end{array}$ \\
\hline 5 & $\begin{array}{l}\text { Mempresentasikan hasil } \\
\text { percobaan }\end{array}$ & 1,0 \\
\hline 6 & $\begin{array}{l}\text { Memperhatikan hasil presentasi } \\
\text { teman }\end{array}$ & 11,5 \\
\hline 7 & Mendengarkan penjelasan guru & 24,5 \\
\hline 8 & Bertanya kepada guru & 4,7 \\
\hline 9 & Bertanya kepada teman & 1,6 \\
\hline 10 & Perilaku tidak relevan & 0,6 \\
\hline \multicolumn{2}{|r|}{ JUMLAH } & $\mathbf{1 0 0}$ \\
\hline
\end{tabular}

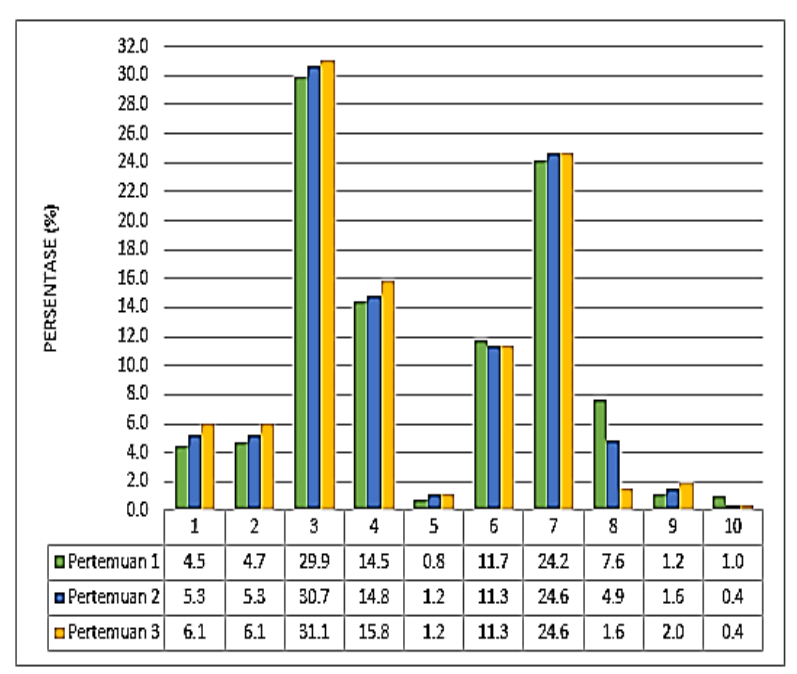

Gambar. 3 Grafik rata-rata persentase aktivitas siswa per pertemuan.

\section{Keterangan:}

1. Merumuskan hipotesis

2. Mengidentifikasi variabel dan merancang percobaan

3. Melakukan percobaan

4. Menganalisis data hasil percobaan dan menuliskan kesimpulan

5. Mempresentasikan hasil percobaan

6. Memperhatikan hasil presentasi teman

7. Mendengarkan penjelasan guru

8. Bertanya kepada guru

9. Bertanya kepada teman

10. Perilaku tidak relevan.

Aktivitas siswa yang terlihat pada Tabel 10 dan Gambar 3 menunjukkan bahwa aktivitas siswa yang jarang dilakukan oleh siswa dalam kegiatan pembelajaran fisika berbasis inkuiri adalah berperilaku tidak relevan kegiatan mempresentasikan hasil percobaan hal ini dikarenakan waktu pembelajaran yang tidak memungkinkan untuk seluruh kelompok atau anggota kelompok mempresentasikan hasil percobaan mereka, hal yang lain juga terjadi pada kegiatan bertanya kepada guru dan teman, hal ini dikarenakan pembelajaran fisika berbasis inkuiri terbimbing masih 
baru bagi siswa dan siswa belum terbiasa dengan model pembelajaran inkuiri.

3. Kendala-kendala yang dialami Selama Proses Penelitian

Kendala-kendala yang dihadapi selama proses pembelajaran dengan menerapkan perangkat pembelajaran fisika berbasis inkuiri terbimbing untuk melatihkan keterampilan proses sains yang telah dikembangkan beserta solusi yang dapat digunakan untuk memperbaiki kendala- kendala tersebut ditunjukkan pada Tabel 11 berikut:

Tabel 11. Kendala-kendala selama proses belajar mengajar

\begin{tabular}{|c|c|c|}
\hline No & & si \\
\hline 1 & $\begin{array}{l}\text { Siswa pada pertemuan } \\
\text { pertama belum terbiasa } \\
\text { dan merasa asing } \\
\text { melakukan eksperimen } \\
\text { dengan menggunakan } \\
\text { keterampilan proses } \\
\text { sains, alokasi waktu } \\
\text { yang digunakan dalam } \\
\text { PBM membutuhkan } \\
\text { waktu lama. }\end{array}$ & \begin{tabular}{lr}
\multicolumn{2}{l}{ Mengorganisir } \\
alokasi waktu agar \\
seluruh kegiatan \\
pembelajaran \\
dilaksanakan \\
tepat dengan \\
melakukan & segiatan \\
tambahan & untuk \\
menjelaskan & \\
komponen & \\
keterampilan & proses \\
sains & \\
\end{tabular} \\
\hline 2 & $\begin{array}{l}\text { Masih ada siswa yang } \\
\text { merasa agak kesulitan } \\
\text { dalam mengikuti } \\
\text { proses belajar mengajar } \\
\text { fisika berbasis inkuiri } \\
\text { terbimbing } \\
\text { melatihkan } \\
\text { keterampilan proses } \\
\text { sains }\end{array}$ & $\begin{array}{lr}\text { Memberi } & \text { motivasi } \\
\text { kepada siswa pada } & \text { saat } r \text { kegiatan } \\
\text { tambahan agar siswa } \\
\text { tidak r merasa } \\
\text { kesulitan untuk } \\
\text { mengikuti proses } \\
\text { belajar mengajar } \\
\text { fisika berbasis inkuiri } \\
\text { terbimbing }\end{array}$ \\
\hline 3 & $\begin{array}{l}\text { Masih ada siswa yang } \\
\text { bermain-main dengan } \\
\text { alat praktikum yang } \\
\text { terbuat dari kaca dan } \\
\text { bahan yang digunakan } \\
\text { saat percobaan }\end{array}$ & $\begin{array}{lr}\text { Mengawasi } & \text { dan } \\
\text { mengingatkan } & \\
\text { kembali siswa } \\
\text { tentang petunjuk } \\
\text { keselamatan dalam } \\
\text { melakukan } \\
\text { percobaan }\end{array}$ \\
\hline
\end{tabular}

\section{B. Deskripsi Hasil Analisis Keefektifan Perangkat Pembelajaran}

1. Analisis Nilai Hasil Belajar

Sebelum diberikan pembelajaran fisika berbasis inkuiri terbimbing untuk melatihkan keterampilan proses sains, siswa diberikan tes awal untuk mengetahui kemampuan awal siswa. Setelah mengikuti seluruh kegiatan pembelajaran, siswa mengerjakan tes akhir untuk mengetahui kemampuan siswa setelah mengikuti kegiatan pembelajaran fisika berbasis inkuiri terbimbing untuk melatihkan keterampilan proses sains. Nilai yang diperoleh dari tes awal dan akhir digunakan untuk mengetahui ketuntasan hasil belajar siswa. Analisis dilakukan berdasarkan data yang diperoleh dari tes awal dan akhir meliputi ketuntasan individu dan sensitivitas soal.

a. Ketuntasan Individual

1) Kompetensi Pengetahuan

Hasil analisis ketuntasan individu pada kompetensi pengetahuan disajikan pada Tabel 12 berikut:

Tabel. 12. Hasil analisis ketuntasan individual kompetensi pengetahuan

\begin{tabular}{|c|c|c|c|c|c|c|c|}
\hline No & $\begin{array}{l}\text { Kode } \\
\text { Siswa }\end{array}$ & NK & $\begin{array}{c}\text { Pre } \\
\text { dik } \\
\text { at }\end{array}$ & Ket & NK & $\begin{array}{c}\text { Pre } \\
\text { dik } \\
\text { at }\end{array}$ & $\begin{array}{l}K \\
\text { et }\end{array}$ \\
\hline 1 & S1 & 1,60 & C- & BT & 3,33 & $\mathrm{~B}+$ & $\mathrm{T}$ \\
\hline 2 & S2 & 2,00 & $\mathrm{C}$ & BT & 3,47 & A- & $\mathrm{T}$ \\
\hline 3 & S3 & 0,53 & $\mathrm{D}$ & BT & 3,20 & $\mathrm{~B}+$ & $\mathrm{T}$ \\
\hline 4 & S4 & 1,33 & $\mathrm{D}+$ & BT & 3,47 & A- & $\mathrm{T}$ \\
\hline 5 & S5 & 1,20 & $\mathrm{D}+$ & BT & 3,33 & $\mathrm{~B}+$ & $\mathrm{T}$ \\
\hline 6 & S6 & 0,53 & $\mathrm{D}$ & BT & 3,33 & $\mathrm{~B}+$ & $\mathrm{T}$ \\
\hline 7 & S7 & 1,87 & $\mathrm{C}$ & BT & 3,20 & $\mathrm{~B}+$ & $\mathrm{T}$ \\
\hline 8 & S8 & 1,60 & C- & BT & 3,47 & A- & $\mathrm{T}$ \\
\hline 9 & S9 & 0,93 & $\mathrm{D}$ & BT & 3,47 & A- & $\mathrm{T}$ \\
\hline 10 & S10 & 2,27 & $\mathrm{C}+$ & BT & 3,60 & A- & $\mathrm{T}$ \\
\hline 11 & S11 & 1,33 & D+ & BT & 3,47 & A- & $\mathrm{T}$ \\
\hline 12 & S12 & 0,53 & $\mathrm{D}$ & BT & 3,60 & A- & $\mathrm{T}$ \\
\hline 13 & S13 & 1,60 & C- & BT & 3,47 & A- & $\mathrm{T}$ \\
\hline 14 & S14 & 1,87 & C & BT & 3,60 & A- & $\mathrm{T}$ \\
\hline 15 & S15 & 0,80 & $\mathrm{D}$ & BT & 3,47 & A- & $\mathrm{T}$ \\
\hline 16 & S16 & 1,33 & $\mathrm{D}+$ & BT & 3,47 & A- & $\mathrm{T}$ \\
\hline 17 & S17 & 1,87 & $\mathrm{C}$ & BT & 3,47 & A- & $\mathrm{T}$ \\
\hline 18 & S18 & 0,53 & $\mathrm{D}$ & BT & 3,47 & A- & $\mathrm{T}$ \\
\hline 19 & S19 & 0,80 & $\mathrm{D}$ & BT & 3,20 & $\mathrm{~B}+$ & $\mathrm{T}$ \\
\hline 20 & S20 & 1,73 & $\mathrm{C}$ & BT & 3,47 & A- & $\mathrm{T}$ \\
\hline 21 & S21 & 1,47 & C- & BT & 3,47 & A- & $\mathrm{T}$ \\
\hline 22 & S22 & 1,33 & $\mathrm{D}+$ & BT & 3,47 & A- & $\mathrm{T}$ \\
\hline 23 & S23 & 1,60 & C- & BT & 3,60 & A- & $\mathrm{T}$ \\
\hline 24 & S24 & 1,60 & C- & BT & 3,47 & A- & $\mathrm{T}$ \\
\hline 25 & S25 & 1,07 & $\mathrm{D}+$ & BT & 3,60 & A- & $\mathrm{T}$ \\
\hline 26 & S26 & 1,73 & $\mathrm{C}$ & BT & 3,60 & A- & $\mathrm{T}$ \\
\hline 27 & S27 & 1,20 & $\mathrm{D}+$ & BT & 3,47 & A- & $\mathrm{T}$ \\
\hline 28 & S28 & 1,47 & C- & BT & 3,33 & $\mathrm{~B}+$ & $\mathrm{T}$ \\
\hline 29 & S29 & 1,60 & C- & BT & 3,47 & A- & $\mathrm{T}$ \\
\hline 30 & S30 & 1,20 & $\mathrm{D}+$ & BT & 3,73 & $\mathrm{~A}$ & $\mathrm{~T}$ \\
\hline 31 & S31 & 1,60 & C- & BT & 3,20 & $\mathrm{~B}+$ & $\mathrm{T}$ \\
\hline 32 & S32 & 1,47 & C- & BT & 3,47 & A- & $\mathrm{T}$ \\
\hline \multicolumn{2}{|c|}{ Rata-rata } & 1,36 & & & 3,50 & & \\
\hline
\end{tabular}

Keterangan:

$$
\begin{array}{ll}
\mathrm{T} & \text { : Tuntas apabila nilai } \geq 3,01 \\
\mathrm{BT} & \text { : Belum tuntas apabila nilai }<3,01 \\
\text { NK } & \text { : Nilai Konversi }
\end{array}
$$

Tabel 12 di atas menunjukkan bahwa pada penelitian ini tidak ada siswa yang tuntas saat dilakukan tes awal, kemudian setelah dilakukan kegiatan belajar mengajar berbasis inkuri terbimbing untuk melatihkan keterampilan proses sains pada topik suhu dan perubahannya sebanyak 32 siswa mencapai ketuntasan individu pada kompetensi pengetahuan. Rata-rata hasil belajar kompetensi pengetahuan setelah dilakukan kegiatan belajar mengajar meningkat dari 1,36 menjadi 
3,50. Hasil belajar kompetensi pengetahuan juga dapat dilihat pada Gambar 4.

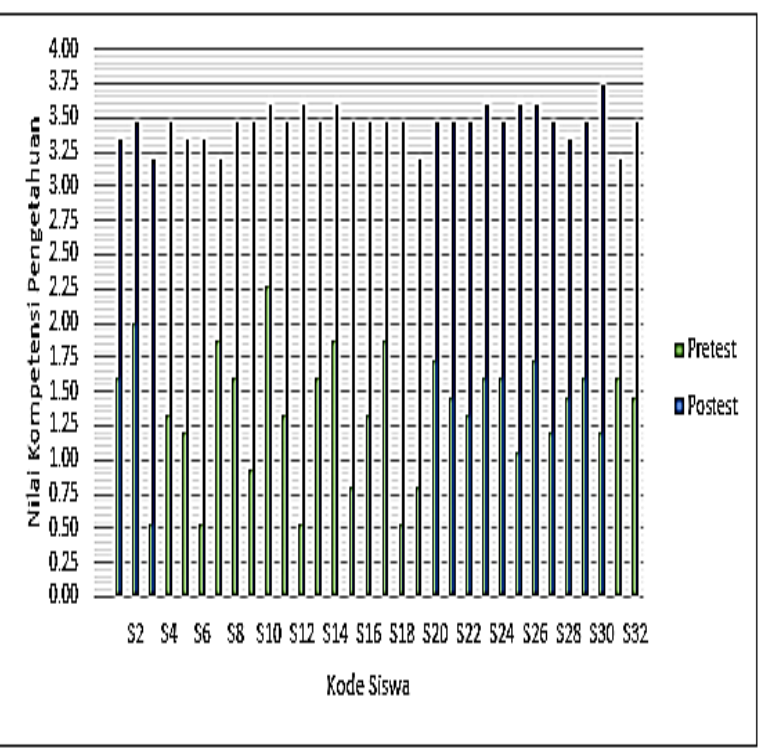

Gambar 4. Grafik hasil analisis ketuntasan belajar kompetensi pengetahuan

Perhitungan skor peningkatan (gain score) hasil belajar kompetensi pengetahuan siswa dapat dilihat pada Tabel 13 berikut:

Tabel 13. Perhitungan $N$-Gain Score hasil belajar kompetensi pengetahuan siswa

\begin{tabular}{|c|c|c|c|c|}
\hline \multirow{2}{*}{$\begin{array}{c}\text { Kode } \\
\text { Siswa }\end{array}$} & \multicolumn{2}{|c|}{ Nilai } & $\begin{array}{c}\text { N-Gain } \\
\text { Score } \\
(\boldsymbol{g})\end{array}$ & $\begin{array}{c}\text { Ketera } \\
\text { ngan }\end{array}$ \\
\cline { 2 - 3 } S1 & Preetest & Posttest & & \\
\hline S2 & 50,0 & 83,3 & 0,72 & tinggi \\
\hline S3 & 13,3 & 86,7 & 0,73 & tinggi \\
\hline S4 & 33,3 & 86,0 & 0,77 & tinggi \\
\hline S5 & 30,0 & 83,3 & 0,80 & tinggi \\
\hline S6 & 13,3 & 83,3 & 0,76 & tinggi \\
\hline S7 & 46,7 & 80,0 & 0,63 & tinggi \\
\hline S8 & 40,0 & 86,7 & 0,78 & tinggi \\
\hline S9 & 23,3 & 86,7 & 0,83 & tinggi \\
\hline S10 & 56,7 & 90,0 & 0,77 & tinggi \\
\hline S11 & 33,3 & 86,7 & 0,80 & tinggi \\
\hline S12 & 13,3 & 90,0 & 0,88 & tinggi \\
\hline S13 & 40,0 & 86,7 & 0,78 & tinggi \\
\hline S14 & 46,7 & 90,0 & 0,81 & tinggi \\
\hline S15 & 20,0 & 86,7 & 0,83 & tinggi \\
\hline S16 & 33,3 & 86,7 & 0,80 & tinggi \\
\hline S17 & 46,7 & 86,7 & 0,75 & tinggi \\
\hline S18 & 13,3 & 86,7 & 0,85 & tinggi \\
\hline S19 & 20,0 & 80,0 & 0,75 & tinggi \\
\hline S20 & 43,3 & 86,7 & 0,76 & tinggi \\
\hline S21 & 36,7 & 86,7 & 0,79 & tinggi \\
\hline S22 & 33,3 & 86,7 & 0,80 & tinggi \\
\hline S23 & 40,0 & 90,0 & 0,83 & tinggi \\
\hline S24 & 40,0 & 86,7 & 0,78 & tinggi \\
\hline S25 & 26,7 & 90,0 & 0,86 & tinggi \\
\hline S26 & 43,3 & 90,0 & 0,82 & tinggi \\
\hline S27 & 30,0 & 86,7 & 0,81 & tinggi \\
\hline S28 & 36,7 & 83,3 & 0,74 & tinggi \\
\hline & & & & \\
\hline S1 & & & & \\
\hline
\end{tabular}

\begin{tabular}{|c|c|c|c|c|}
\hline \multirow{2}{*}{$\begin{array}{l}\text { Kode } \\
\text { Siswa }\end{array}$} & \multicolumn{2}{|c|}{ Nilai } & \multirow{2}{*}{$\begin{array}{c}\text { N-Gain } \\
\text { Score } \\
(\mathrm{g})\end{array}$} & \multirow{2}{*}{$\begin{array}{c}\text { Ketera } \\
\text { ngan }\end{array}$} \\
\hline & Preetest & Posttest & & \\
\hline S29 & 40,0 & 86,7 & 0,78 & tinggi \\
\hline S30 & 30,0 & 93,3 & 0,90 & tinggi \\
\hline S31 & 40,0 & 80,0 & 0,67 & sedang \\
\hline S32 & 36,7 & 86,7 & 0,79 & tinggi \\
\hline \multicolumn{3}{|c|}{ Rata-rata N-Gain Score } & 0,79 & Tinggi \\
\hline
\end{tabular}

Berdasarkan Tabel 13 di atas dapat dilihat bahwa skor peningkatan (gain score) pada hasil belajar kompetensi pengetahuan siswa dikategorikan sebagai gtinggi dengan rata-rata 0,79 atau $79 \%$.

2) Kompetensi Keterampilan Proses Sains

Hasil analisis ketuntasan individual pada aspek keterampilan disajikan pada Tabel 14 berikut:

Tabel 14. Hasil analisis ketuntasan individual kompetensi keterampilan

\begin{tabular}{|c|c|c|c|c|c|c|c|}
\hline No & $\begin{array}{l}\text { Kode } \\
\text { Siswa }\end{array}$ & NK & $\begin{array}{l}\text { Pred } \\
\text { ikat }\end{array}$ & Ket & NK & $\begin{array}{l}\text { Pre } \\
\text { dik } \\
\text { at }\end{array}$ & $\begin{array}{l}\text { K } \\
\text { et }\end{array}$ \\
\hline 1 & S1 & 1,33 & D+ & BT & 3,41 & A- & T \\
\hline 2 & S2 & 1,33 & D+ & BT & 3,26 & B+ & T \\
\hline 3 & S3 & 1,33 & D+ & BT & 3,41 & A- & T \\
\hline 4 & S4 & 1,33 & D+ & BT & 3,26 & B+ & T \\
\hline 5 & S5 & 1,33 & D+ & BT & 3,26 & B+ & T \\
\hline 6 & S6 & 1,33 & D+ & BT & 3,26 & B+ & T \\
\hline 7 & S7 & 1,33 & D+ & BT & 3,26 & B+ & T \\
\hline 8 & S8 & 1,33 & D+ & BT & 3,41 & A- & T \\
\hline 9 & S9 & 1,33 & D+ & BT & 3,41 & A- & T \\
\hline 10 & S10 & 1,33 & D+ & BT & 3,41 & A- & T \\
\hline 11 & S11 & 1,33 & D+ & BT & 3,41 & A- & T \\
\hline 12 & S12 & 1,33 & D+ & BT & 3,41 & A- & T \\
\hline 13 & S13 & 1,33 & D+ & BT & 3,26 & B+ & T \\
\hline 14 & S14 & 1,33 & D+ & BT & 3,26 & B+ & T \\
\hline 15 & S15 & 1,33 & D+ & BT & 3,41 & A- & T \\
\hline 16 & S16 & 1,33 & D+ & BT & 3,26 & B+ & T \\
\hline 17 & S17 & 1,33 & D+ & BT & 3,41 & A- & T \\
\hline 18 & S18 & 1,33 & D+ & BT & 3,26 & B+ & T \\
\hline 19 & S19 & 1,33 & D+ & BT & 3,26 & B+ & T \\
\hline 20 & S20 & 1,33 & D+ & BT & 3,41 & A- & T \\
\hline 21 & S21 & 1,33 & D+ & BT & 3,41 & A- & T \\
\hline 22 & S22 & 1,33 & D+ & BT & 3,26 & B+ & T \\
\hline 23 & S23 & 1,33 & D+ & BT & 3,41 & A- & T \\
\hline 24 & S24 & 1,33 & D+ & BT & 3,41 & A- & T \\
\hline 25 & S25 & 1,33 & D+ & BT & 3,26 & B+ & T \\
\hline 26 & S26 & 1,33 & D+ & BT & 3,26 & B+ & T \\
\hline 27 & S27 & 1,33 & D+ & BT & 3,41 & A- & T \\
\hline 28 & S28 & 1,33 & D+ & BT & 3,26 & B+ & T \\
\hline 29 & S29 & 1,33 & D+ & BT & 3,41 & A- & T \\
\hline 30 & S30 & 1,33 & D+ & BT & 3,26 & B+ & T \\
\hline 31 & S31 & 1,33 & D+ & BT & 3,26 & B+ & T \\
\hline 32 & S32 & 1,33 & D+ & BT & 3,11 & B+ & T \\
\hline Rata-rata & & & & & & \\
\hline Keterangan & & & & & \\
\hline
\end{tabular}

Keterangan:

$\mathrm{T} \quad$ : Tuntas apabila nilai $\geq 3,01$

BT : Belum tuntas apabila nilai $<3,01$

NK : Nilai Konversi 
Tabel 14 di atas diperoleh informasi bahwa pada penelitian ini seluruh siswa tidak tuntas pada saat dilakukan tes awal, hal ini disebabkan siswa belum terbiasa mengerjakan tes hasil belajar kompetensi keterampilan berupa tes kinerja, kemudian setelah dilakukan kegiatan belajar mengajar berbasis inkuri terbimbing untuk melatihkan keterampilan proses sains, seluruh siswa mencapai ketuntasan individual untuk kompetensi keterampilan dengan nilai kompetensi di atas 3,01 (urusan kurikulum SMPN 1 Muara Jawa) hal ini menunjukkan bahwa penerapan perangkat pembelajaran berbasis inkuiri terbimbing dapat melatihkan keterampilan proses sains siswa, hasil belajar kompetensi keterampilan juga dapat dilihat pada Gambar 5.

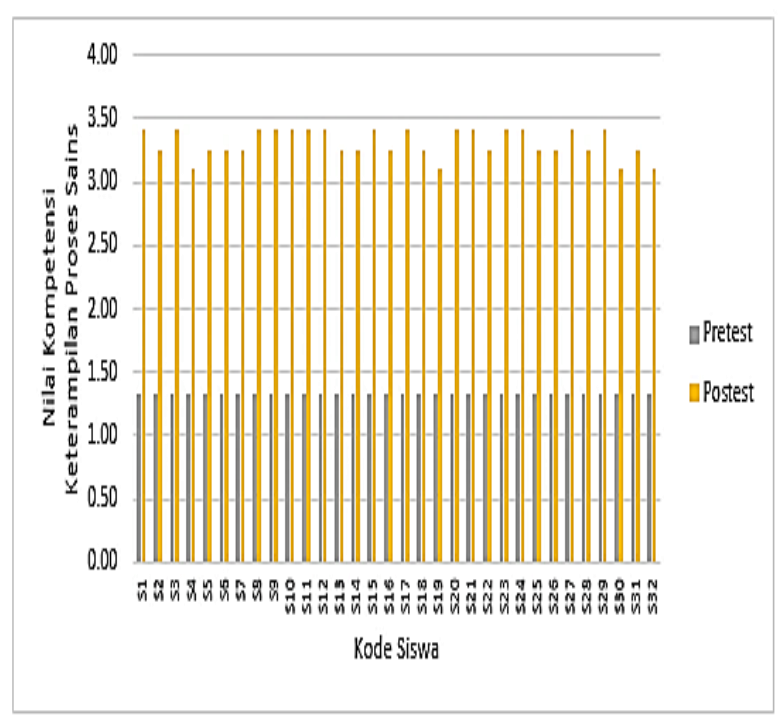

Gambar 5. Grafik hasil analisis ketuntasan belajar kompetensi keterampilan

Perhitungan skor peningkatan (gain score) hasil belajar kompetensi keterampilan siswa dapat dilihat pada Tabel 15 berikut:

Tabel 15. Perhitungan $N$-Gain Score hasil belajar kompetensi keterampilan siswa

\begin{tabular}{|l|l|l|l|c|}
\hline \multirow{2}{*}{$\begin{array}{c}\text { Kode } \\
\text { Siswa }\end{array}$} & \multicolumn{2}{|c|}{ Nilai } & $\begin{array}{c}\boldsymbol{N}- \\
\text { Gain } \\
\text { Score } \\
(\boldsymbol{g})\end{array}$ & Keterangan \\
\hline S1 & 33,33 & 85,19 & 0,78 & Tinggi \\
\hline S2 & 33,33 & 81,48 & 0,72 & Tinggi \\
\hline S3 & 33,33 & 85,19 & 0,78 & Tinggi \\
\hline S4 & 33,33 & 81,48 & 0,72 & Tinggi \\
\hline S5 & 33,33 & 81,48 & 0,72 & Tinggi \\
\hline S6 & 33,33 & 81,48 & 0,72 & Tinggi \\
\hline S7 & 33,33 & 81,48 & 0,72 & Tinggi \\
\hline S8 & 33,33 & 85,19 & 0,78 & Tinggi \\
\hline
\end{tabular}

\begin{tabular}{|l|l|l|l|l|}
\hline \multirow{2}{*}{$\begin{array}{c}\text { Kode } \\
\text { Siswa }\end{array}$} & \multicolumn{2}{|c|}{ Nilai } & $\begin{array}{c}\boldsymbol{N} \text { - } \\
\text { Gain } \\
\text { Score } \\
(\boldsymbol{g})\end{array}$ & Keterangan \\
\hline S9 & 33,33 & 85,19 & 0,78 & Tinggi \\
\hline S10 & 33,33 & 85,19 & 0,78 & Tinggi \\
\hline S11 & 33,33 & 85,19 & 0,78 & Tinggi \\
\hline S12 & 33,33 & 85,19 & 0,78 & Tinggi \\
\hline S13 & 33,33 & 81,48 & 0,72 & Tinggi \\
\hline S14 & 33,33 & 81,48 & 0,72 & Tinggi \\
\hline S15 & 33,33 & 85,19 & 0,78 & Tinggi \\
\hline S16 & 33,33 & 81,48 & 0,72 & Tinggi \\
\hline S17 & 33,33 & 85,19 & 0,78 & Tinggi \\
\hline S18 & 33,33 & 81,48 & 0,72 & Tinggi \\
\hline S19 & 33,33 & 81,48 & 0,72 & Tinggi \\
\hline S20 & 33,33 & 85,19 & 0,78 & Tinggi \\
\hline S21 & 33,33 & 85,19 & 0,78 & Tinggi \\
\hline S22 & 33,33 & 81,48 & 0,72 & Tinggi \\
\hline S23 & 33,33 & 85,19 & 0,78 & Tinggi \\
\hline S24 & 33,33 & 85,19 & 0,78 & Tinggi \\
\hline S25 & 33,33 & 81,48 & 0,72 & Tinggi \\
\hline S26 & 33,33 & 81,48 & 0,72 & Tinggi \\
\hline S27 & 33,33 & 85,19 & 0,78 & Tinggi \\
\hline S28 & 33,33 & 81,48 & 0,72 & Tinggi \\
\hline S29 & 33,33 & 85,19 & 0,78 & Tinggi \\
\hline S30 & 33,33 & 81,48 & 0,72 & Tinggi \\
\hline S31 & 33,33 & 81,48 & 0,72 & Tinggi \\
\hline S32 & 33,33 & 77,78 & 0,67 & Sedang \\
\hline Rata-rata $\boldsymbol{N}-$ Gain & Score & 0,75 & Tinggi \\
\hline
\end{tabular}

Berdasarkan Tabel 15 di atas dapat dilihat bahwa skor peningkatan (gain score) pada hasil belajar kompetensi keterampilan siswa dikategorikan sebagai g-tinggi dengan rata-rata 0,75 atau $75 \%$.

\section{3) Kompetensi Sikap}

Penilaian sikap yang dilakukan pada penelitian ini adalah penilaian pada sikap siswa yang penilaiannya dilakukan saat proses belajar mengajar dilakukan dengan melihat rata-rata perkembangan sikap siswa per aspek mulai dari pertemuan pertama sampai pertemuan ketiga yang secara rinci disajikan pada Tabel 16 berikut: 
Tabel 16. Hasil analisis penilaian sikap ilmiah siswa

\begin{tabular}{|c|c|c|c|c|c|c|c|c|c|c|}
\hline \multirow{3}{*}{ Ko. Siswa } & \multicolumn{10}{|c|}{ Aspek Sikap Siswa } \\
\hline & \multicolumn{2}{|c|}{1} & \multicolumn{2}{|c|}{2} & \multicolumn{2}{|c|}{3} & \multicolumn{2}{|c|}{4} & \multicolumn{2}{|c|}{5} \\
\hline & $\mathbf{R}$ & PR & $\mathbf{R}$ & PR & $\mathbf{R}$ & PR & $\mathbf{R}$ & PR & $\mathbf{R}$ & PR \\
\hline S1 & 4,0 & SB & 3,0 & $\mathrm{~B}$ & 3,3 & B & 3,7 & SB & 3,7 & SB \\
\hline $\mathrm{S} 2$ & 4,0 & SB & 3,3 & $\mathrm{~B}$ & 3,7 & SB & 3,3 & B & 3,3 & B \\
\hline S3 & 4,0 & SB & 3,0 & B & 3,0 & B & 3,0 & B & 3,0 & B \\
\hline S4 & 4,0 & SB & 3,0 & $\mathrm{~B}$ & 3,0 & $\mathrm{~B}$ & 3,0 & B & 3,0 & $\mathrm{~B}$ \\
\hline S5 & 4,0 & SB & 3,0 & B & 3,0 & $\mathrm{~B}$ & 3,0 & B & 3,0 & B \\
\hline S6 & 4,0 & SB & 3,0 & $\mathrm{~B}$ & 3,0 & $\mathrm{~B}$ & 3,0 & $\mathrm{~B}$ & 3,0 & $\mathrm{~B}$ \\
\hline S7 & 4,0 & SB & 3,0 & B & 3,0 & B & 3,0 & $\mathrm{~B}$ & 3,0 & $\mathrm{~B}$ \\
\hline S8 & 4,0 & SB & 3,0 & B & 3,3 & B & 3,7 & SB & 3,3 & B \\
\hline S9 & 4,0 & SB & 3,0 & $\mathrm{~B}$ & 3,0 & $\mathrm{~B}$ & 3,3 & $\mathrm{~B}$ & 3,7 & SB \\
\hline S10 & 4,0 & SB & 3,7 & SB & 4,0 & SB & 4,0 & SB & 4,0 & SB \\
\hline S11 & 4,0 & SB & 3,3 & $\mathrm{~B}$ & 3,3 & $\mathrm{~B}$ & 3,3 & B & 3,3 & B \\
\hline S12 & 4,0 & SB & 3,0 & $\mathrm{~B}$ & 3,0 & $\mathrm{~B}$ & 3,0 & B & 3,0 & B \\
\hline S13 & 4,0 & SB & 3,3 & B & 3,3 & $\mathrm{~B}$ & 3,7 & SB & 3,3 & $\mathrm{~B}$ \\
\hline S14 & 4,0 & SB & 3,3 & B & 3,3 & B & 3,3 & $\mathrm{~B}$ & 3,3 & B \\
\hline S15 & 4,0 & SB & 3,0 & B & 3,0 & B & 3,0 & B & 3,3 & B \\
\hline S16 & 4,0 & SB & 3,0 & B & 3,0 & B & 3,0 & B & 3,0 & B \\
\hline S17 & 4,0 & SB & 3,7 & SB & 4,0 & SB & 4,0 & SB & 4,0 & SB \\
\hline S18 & 4,0 & SB & 3,0 & B & 3,0 & B & 3,0 & B & 3,0 & B \\
\hline S19 & 4,0 & SB & 3,0 & B & 3,0 & B & 3,0 & B & 3,0 & B \\
\hline $\mathrm{S} 20$ & 4,0 & SB & 3,7 & SB & 3,7 & SB & 4,0 & SB & 4,0 & SB \\
\hline S21 & 4,0 & SB & 3,7 & SB & 3,7 & SB & 3,7 & SB & 4,0 & SB \\
\hline S22 & 4,0 & SB & 3,3 & B & 3,3 & B & 3,3 & B & 3,7 & SB \\
\hline $\mathrm{S} 23$ & 4,0 & SB & 3,7 & SB & 3,7 & SB & 3,7 & SB & 4,0 & SB \\
\hline S24 & 4,0 & SB & 3,0 & $\mathrm{~B}$ & 3,0 & B & 3,0 & B & 3,0 & B \\
\hline S25 & 4,0 & SB & 3,3 & B & 3,3 & B & 3,7 & SB & 3,7 & SB \\
\hline S26 & 4,0 & SB & 3,7 & SB & 3,7 & SB & 3,7 & SB & 4,0 & SB \\
\hline S27 & 4,0 & SB & 3,0 & B & 3,0 & B & 3,0 & B & 3,0 & B \\
\hline S28 & 4,0 & SB & 3,0 & B & 3,0 & B & 3,0 & B & 3,0 & B \\
\hline S29 & 4,0 & SB & 3,0 & B & 3,0 & B & 3,0 & B & 3,0 & B \\
\hline S30 & 4,0 & SB & 3,3 & B & 3,3 & B & 3,3 & B & 3,7 & SB \\
\hline S31 & 4,0 & SB & 3,0 & B & 3,0 & B & 3,0 & B & 3,0 & B \\
\hline S32 & 4,0 & SB & 3,0 & B & 3,0 & B & 3,0 & B & 3,0 & B \\
\hline
\end{tabular}

Keterangan:

1. Menghayati dan mengamalkan ajaran agama yang dianutnya

2. Rasa ingin tahu

3. Hati-hati

4. Tanggung Jawab

5. Sikap dalam berkomunikasi

$\mathrm{R}$ = Rata-rata

$\mathrm{PR}=$ Predikat

$\mathrm{P}=$ Pertemuan/Tatap muka

Sikap siswa terlihat pada Tabel 16 dan Gambar 6,

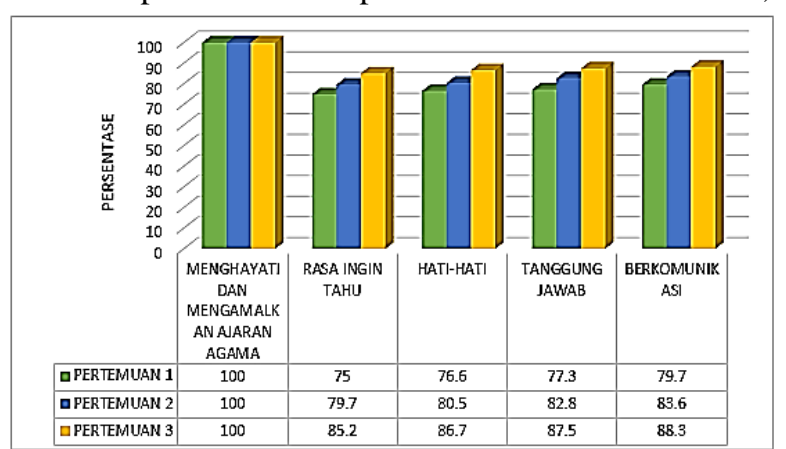

Gambar 6. Grafik hasil analisis ketuntasan belajar kompetensi sikap.

\section{b. Sensitivitas}

Tabel 17 menunjukkan sentitivitas butir soal pada aspek pengetahuan yang menyatakan kepekaan butir soal terhadap pengaruh proses kegiatan belajar mengajar, Butir soal dikatakan memiliki kepekaan terhadap proses kegiatan belajar mengajar apabila memiliki sensitivitas $\geq 0,3$ (Gronlund, 1982; Aiken, 1997). Semakin tinggi nilai sensitivitas yang dimiliki oleh butir soal, maka butir soal tersebut memiliki kepekaan terhadap proses pembelajaran yang dilakukan. Tabel 17. Sensitivitas butir soal kompetensi pengetahuan

\begin{tabular}{|c|c|c|c|c|}
\hline $\begin{array}{c}\text { Butir } \\
\text { Soal }\end{array}$ & Pretest & Postest & Sensitivitas & Kategori \\
\hline 1 & 18 & 32 & 0,4 & Sensitif \\
\hline 2 & 16 & 32 & 0,5 & Sensitif \\
\hline 3 & 14 & 29 & 0,5 & Sensitif \\
\hline 4 & 20 & 32 & 0,4 & Sensitif \\
\hline 5 & 21 & 31 & 0,3 & Sensitif \\
\hline 6 & 7 & 25 & 0,6 & Sensitif \\
\hline 7 & 3 & 24 & 0,7 & Sensitif \\
\hline 8 & 6 & 26 & 0,6 & Sensitif \\
\hline
\end{tabular}




\begin{tabular}{|c|c|c|c|c|}
\hline $\begin{array}{l}\text { Butir } \\
\text { Soal }\end{array}$ & Pretest & Postest & Sensitivitas & Kategori \\
\hline 9 & 7 & 24 & 0,5 & Sensitif \\
\hline 10 & 13 & 32 & 0,6 & Sensitif \\
\hline 11 & 5 & 25 & 0,6 & Sensitif \\
\hline 12 & 10 & 30 & 0,6 & Sensitif \\
\hline 13 & 15 & 26 & 0,3 & Sensitif \\
\hline 14 & 12 & 29 & 0,5 & Sensitif \\
\hline 15 & 3 & 24 & 0,7 & Sensitif \\
\hline 16 & 6 & 29 & 0,7 & Sensitif \\
\hline 17 & 13 & 27 & 0,4 & Sensitif \\
\hline 18 & 6 & 24 & 0,6 & Sensitif \\
\hline 19 & 21 & 31 & 0,3 & Sensitif \\
\hline 20 & 4 & 24 & 0,6 & Sensitif \\
\hline 21 & 18 & 32 & 0,4 & Sensitif \\
\hline 22 & 5 & 24 & 0,6 & Sensitif \\
\hline 23 & 0 & 24 & 0,8 & Sensitif \\
\hline 24 & 16 & 31 & 0,5 & Sensitif \\
\hline 25 & 10 & 25 & 0,5 & Sensitif \\
\hline 26 & 8 & 24 & 0,5 & Sensitif \\
\hline 27 & 13 & 30 & 0,5 & Sensitif \\
\hline 28 & 17 & 30 & 0,4 & Sensitif \\
\hline 29 & 9 & 24 & 0,5 & Sensitif \\
\hline 30 & 11 & 28 & 0,5 & Sensitif \\
\hline & Rata-rata & 0,5 & Sensitif \\
\hline
\end{tabular}

\begin{tabular}{|l|l|l|l|}
\hline No & Pertanyaan & $\begin{array}{l}\text { Respon } \\
\text { Siswa }\end{array}$ & $\begin{array}{l}\text { Perse } \\
\text { ntase }\end{array}$ \\
\hline & $\begin{array}{l}\text { belajar, dan cara guru } \\
\text { mengajar. }\end{array}$ & $\begin{array}{l}\text { Minat siswa terhadap } \\
\text { pembelajaran inkuiri } \\
\text { terbimbing }\end{array}$ & Berminat \\
\hline 5 & $\begin{array}{l}\text { Kejelasan pada kegiatan } \\
\text { belajar mengajar }\end{array}$ & Jelas & $100 \%$ \\
\hline 6 & $\begin{array}{l}\text { Ketertarikan pada } \\
\text { keterampilan proses } \\
\text { sains }\end{array}$ & Tertarik & $99 \%$ \\
\hline 7 & $\begin{array}{l}\text { Kemudahan menjawab } \\
\text { soal }\end{array}$ & Mudah & $100 \%$ \\
\hline
\end{tabular}

Tabel 18 menunjukkan bahwa respon positif siswa pada pembelajaran berbasis inkuiri terbimbing untuk melatihkan keterampilan proses sains berkategori sangat kuat sebab 98\% siswa tertarik, $100 \%$ siswa merasa baru dengan komponen pembelajaran inkuiri terbimbing, $99 \%$ siswa merasa mudah dalam memahami komponen pembelajaran hal ini berarti hanya 1 persen siswa yang merasa tidak mudah memahami komponen pembelajaran menggunakan model inkuiri terbimbing, $100 \%$ siswa berminat terhadap pembelajaran inkuiri terbimbing, $100 \%$ siswa merasa jelas terhadap penjelasan guru, 99\% siswa tertarik dengan keterampilan proses sains, dan $100 \%$ siswa merasa mudah menjawab soal.

Tabel 17 menunjukkan bahwa seluruh soal yang berjumlah 30 butir soal pada kompetensi pengetahuan memiliki sensitivitas di atas 0,3 dengan rata-rata sensitivitas 0,5 , berdasarkan data tersebut maka seluruh soal dikatakan sensitif sehingga butir soal secara umum dinyatakan peka terhadap proses pembelajaran.

\section{Respon Siswa}

Hasil analisis respon siswa terhadap perangkat pembelajaran, suasana belajar, cara guru mengajar, dan tes hasil belajar secara lengkap disajikan pada Tabel 18 berikut:

Tabel 18. Hasil analisis respon siswa

\begin{tabular}{|c|c|c|c|}
\hline No & Pertanyaan & $\begin{array}{l}\text { Respon } \\
\text { Siswa }\end{array}$ & $\begin{array}{l}\text { Perse } \\
\text { ntase }\end{array}$ \\
\hline 1 & $\begin{array}{l}\text { Ketertarikan } \\
\text { terhadap kiswa } \\
\text { materi, buku siswa, } \\
\text { LKS, suasana belajar, } \\
\text { dan cara guru mengajar. }\end{array}$ & Tertarik & $98 \%$ \\
\hline 2 & $\begin{array}{l}\text { Keterbaruan } \\
\text { terhadap kiswa } \\
\text { materi, buku siswa, } \\
\text { LKS, suasana belajar, } \\
\text { dan cara guru mengajar. }\end{array}$ & Baru & $100 \%$ \\
\hline 3 & 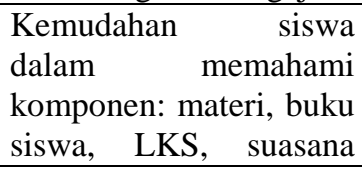 & Mudah & $99 \%$ \\
\hline
\end{tabular}

\section{KESIMPULAN}

\section{A. Simpulan}

Berdasarkan hasil analisis, diskusi dan pembahasan, maka diperoleh simpulan secara umum bahwa perangkat pembelajaran fisika berbasis inkuiri terbimbing yang dikembangkan berkategori sangat valid, praktis serta efektif untuk melatihkan keterampilan proses sains siswa SMP dan meningkatkan hasil belajar siswa.

\section{B. Saran}

Berdasarkan dari hasil penelitian yang telah dilakukan, ada beberapa saran yang dapat dikemukakan peneliti, sebagai berikut:

1. Pembelajaran fisika berbasis inkuiri terbimbing untuk melatihkan keterampilan proses sains memerlukan waktu lama, sehingga disarankan perlu waktu sebanyak satu kali pertemuan sebelum pembelajaran untuk memperkenalkan kepada siswa tentang keterampilan proses sains,

2. Pemberian motivasi kepada siswa sangat diperlukan agar tidak merasa kesulitan dalam mengikuti proses pembelajaran yang berbasis inkuiri terbimbing untuk melatihkan keterampilan proses sains,

3. Pengawasan dan mengingatkan siswa tentang petunjuk keselamatan kerja dalam melakukan 
percobaan sangat diperlukan agar tidak terjadi halhal yang tidak diinginkan selama kegiatan percobaan berlangsung.

\section{REFERENSI}

Aiken, L. (1997). Psychological testting and assessment 9th edition. USA: Allyn and Bacon.

Ambarsari, W., Santosa, S., \& Maridi. (2013). "Penerapan pembelajaran inkuiri terbimbing terhadap keterampilan proses sains dasar pada pelajaran biologi siswa kelas VIII SMP Negeri 7 Surakarta”. Jurnal Pendidikan Biologi. Vol. 5 No. 1. Januari 2013. pp 81-95.

Arifin, Z. (2009). Evaluasi pembelajaran. Bandung: PT Remaja Rosda Karya.

Arikunto, S. (2006). Dasar-dasar evaluasi pendidikan. edisi revisi. Jakarta: PT. Bumi Aksara.

Borich. G.D. (1994). Observation skill for effective teaching. Second Edition. New York: Macmillan Publishing Company.

Dewi, K., Sadia, I.W., \& Ristiati, N.P. (2013). "Pengembangan perangkat pembelajaran IPA terpadu dengan setting inkuiri terbimbing untuk meningkatkan pemahaman konsep dan kinerja ilmiah”. E-journal PPs Universitas Pendidikan Ganesha. Vol.3 2013. pdf. Diakses 10 Maret 2014.

Dimyati \& Mudjiono. (2009). Belajar dan pembelajaran. Jakarta: Rineka Cipta.

Eggen, P., \& Kauchak, D. (1996). Strategies for teacher; teaching content and thinking skills. USA: Allyn and Bacon.

Gronlund, N.E. (1982). Constructing achievement test. third edition. USA. Prentice Hall Inc.

Hake. (1999). Analyzing change/gain scores. (Online). Tersedia http://www. physicsindiana.edu/sdi/Analyzing-Change-Gain. pdf. Diakses 15 November 2013.

Ibrahim, M.H. (2012). Pembelajaran inkuiri (Makalah disajikan pada Diklat Nasional, Surabaya).

Kementerian Pendidikan dan Kebudayaan Republik Indonesia. (2013). Ilmu pengetahuan alam: Buku Guru/ Kementerian Pendidikan dan Kebudayaan. Jakarta: Kementerian Pendidikan dan Kebudayaan.

Kementerian Pendidikan dan Kebudayaan Republik Indonesia. (2013). Modul pelatihan implementasi kurikulum 2013. Jakarta: Kementerian Pendidikan dan Kebudayaan.

Kementerian Pendidikan dan Kebudayaan Republik Indonesia. (2013). Salinan lampiran peraturan Menteri pendidikan dan Kebudayaan Republik
Indonesia No. 54 Tahun 2013. Yang diundangkan di Jakarta tanggal 17 Mei 2013 oleh Kemenkumham RI Pada berita acara RI tahun 2013 No. 712. Jakarta: Kementerian Pendidikan dan Kebudayaan.

Kementerian Pendidikan dan Kebudayaan Republik Indonesia. (2013). Salinan lampiran peraturan Menteri pendidikan dan Kebudayaan Republik Indonesia No. 81A Tahun 2013.. Jakarta: Kementerian Pendidikan dan Kebudayaan.

Kim, E.C., \& Kellough, R.D. (1995). A resource guide for secondary school teaching: planning for competence 6Th. USA: Prentice-Hall, Inc.

Maloney, J., \& Simon, S. (2007). Mapping children's discussions of evidence in science to assess collaboration and argumentation. Journal International of Science Education, 28 (15): 18171841.

Orlich D.C., Harder, R.J., Callahan, R.C., Trevisan, M.S., \& Brown, A.H. (2010). Teaching strategies a guide to effective instruction: ninth edition. USA: Wadsworth, Cengage Learning.

Pinto, R., \& Boudamoussi, S.E. (2009). "Scientific processes in PISA test observed for science teacher". International Jurnal of Science Education. Vol. 31, No. 16, November 2009, pp. 2131-2159.

Ratumanan, G.T., \& Laurens, T. (2011). Evaluasi hasil belajar pada tingkat satuan pendidikan. Surabaya: Unesa Unversity Press.

Ridwan. (2010). Skala pengukuran variabel-variabel penelitian. Bandung: Alfabeta.

Schwarz, C., \& Gwekwerere, Y. (2007). "Using a guided inquiry and modeling instructional framework (EIMA) to support pre-service K-8 science teaching". Science Education Journal, 91(1), 158-186.

Slavin, R.E. (2008). Psikologi pendidikan, teori dan praktik edisi kedelapan jilid 1. Jakarta: PT. Indeks.

Subagyo, Y., Wiyanto., \& Marwoto, P. (2009). "Pembelajaran dengan pendekatan keterampilan proses sains untuk meningkatkan penguasaan konsep suhu dan pemuaian". Jurnal Pendidikan Fisika Indonesia. Vol 5, Januari 2009. pp 42-46.

Thiagarajan, S., Semmel, D.S., \& Semmel, M.I. (1974) Instructional development for training teacher of exceptional children: a sourcebook. Washington, D.C: National Center for Improvement of Educational System (DHEW/OE).

Tuckman, B.W. (1999). Conducting educational research; fifth edition. USA: Harcourt Brace \& College Publisher. 